\title{
Two Cheers for Lost Sovereignty Referendums: Campaigns for Independence and the Pouvoir Constituant Mixte
}

\author{
Peter Niesen $^{1}$ (D) \\ ${ }^{1}$ Universität Hamburg, Hamburg, Germany \\ Corresponding author: peter.niesen@uni-hamburg.de
}

(Received 08 May 2021; accepted 23 August 2021)

\begin{abstract}
In this article, I bring together three recent ideas from political theory and constitutional law. The first is the notion developed by Jürgen Habermas and Markus Patberg of a pouvoir constituant mixte. Complex polities such as supra-state federations should be understood as constitutional entities that combine two or more authorizing subjects. The default "mixed" conception is that of dual sovereignty, split between the federations' member collectives and member individuals. The second idea is that of Stephen Tierney, that sub-state national societies should be seen as involved in struggles over constituent power. The third is the idea and practice of sovereignty referendums, which I illustrate by looking at the 2017 Catalonia independence referendum. I contend that, at a minimum, sovereignty referendums, especially lost ones, should be understood as strategies to bring about, shift or complement constituent powers, in achieving compound or mixed sovereignty. Finally, I venture into some ideas about the criteria of legitimacy for such endeavors, in distinguishing the activation of constituent powers from their articulation and exercise.
\end{abstract}

Keywords: Pouvoir constituant mixte; constitutional law; sub-state national societies; sovereignty referendums; split sovereignty

\section{A. Introduction}

If you allow that highly integrated federations typically rely on a dual or "split" allocation of constituent powers, with the citizenry of the member states and with the citizenry of the federation as constituent subjects, and that the European Union instantiates such a pouvoir constituant mixte, then Brexit has illustrated an implicit corollary. It has demonstrated the permanent possibility that holdership and even existence of constituent powers can undergo changes. Discontinuing membership in a supra-state polity entails that, on the part of the exiting country, a dual pouvoir constituant will be reduced to the pre-existing unitary one.

Such dynamic changes in constituent powers on the supra-state level are increasingly being mirrored on the state level. Independence movements in sub-state national societies such as Quebec, Scotland, Flanders, or Catalonia, traditionally examined through the prism of struggles for secession and sovereignty, suggest that even within existing states, new constituent powers can

Peter Niesen is Professor of Political Theory at Universität Hamburg. From 2006 to 2013, he was Professor of Political Theory and History of Ideas at Technische Universität Darmstadt and a member of the Frankfurt-based research cluster "Formation of Normative Orders". He is the author of 'Anti-Extremism, Negative Republicanism, Civic Society: Three Paradigms for Banning Political Parties', German Law Journal 2002.

(C) The Author(s) 2022. Published by Cambridge University Press on behalf of the German Law Journal. This is an Open Access article, distributed under the terms of the Creative Commons Attribution licence (https://creativecommons.org/licenses/by/4.0/), which permits unrestricted re-use, distribution, and reproduction in any medium, provided the original work is properly cited. 
emerge or subsist. ${ }^{1}$ The aim of this article is to show that, minimally, sovereignty referendums staged by independence campaigns are attempts to effect a revitalization or change in the ontology of constituent powers, and that these attempts tend to be successful one way or another. Even where such campaigns do not achieve full political autonomy for the collective in question, they will create new, revive, or stabilize pre-existing sub-state pouvoirs constituants, and will affirm or cause the emergence of new sub-state national societies among their holders. However, results should be distinguished as to whether they allow for a complete break and revision of pouvoirs constituants, as in Brexit and more traditional cases of secession, or for their multi-level reallocation along the lines of a pouvoir constituant mixte. The latter cases will trigger a less radical reorganization of powers than what the rhetoric of independence referendums promises, but they also offer to create a significant new playing field for the negotiation of conflicts. ${ }^{2}$ At the same time, they raise questions about their conditions of legitimacy which have not been settled in the traditional discourses on secession and sovereignty.

While much of traditional legal and political theory has stressed the sheer facticity of successful political mobilization toward sovereignty, I ask whether the transferal and emergence of constituent powers in sovereignty referendums underlies normative constraints. Is there a democratic way to fuse, fragment, change, or create new subjects of constituent power? So far, the literature has discussed sovereignty referendums mainly on the basis of substantive conditions of legitimacy for secession, such as the prior existence of collectives, unified in culture, language, history, or territory. ${ }^{3}$ In contrast, I suggest that research should focus on processual features in the creation and change of constituent powers. Again, the literature has focused on the authorization of exercises of constituent power considered as a fixed quantity, ${ }^{4}$ but rarely on the shift or emergence of constituent powers as their aim or by-product. Building on a preliminary taxonomy of articulation, activation, and exercise of constituent power, ${ }^{5}$ I argue that the normative debate on sovereignty referendums should take note of the conditions of legitimacy of activating new pouvoirs constituants.

\footnotetext{
${ }^{1}$ Stephen Tierney, 'We the Peoples': Constituent Power and Constitutionalism in Plurinational States, in THE PARADOX OF Constitutionalism: Constituent Power and Constitutional Form 229-245 (Martin Loughlin \& Neil Walker eds.) [hereinafter Tierney, We the Peoples].

${ }^{2}$ Claims to self-determination of indigenous peoples (First Nations) within settler states such as Australia or Canada are increasingly discussed in the language of constituent power. See Paul Muldoon \& Andrew Schaap, Aboriginal Sovereignty and the Politics of Reconciliation: The Constituent Power of the Aboriginal Embassy in Australia, 30 ENV'T AND PLAN. D: SOC'Y AND SpaCe 381, 534-50 (2012); John Grant, Lived Fictions: Unity and ExClusion in Canadian Politics 111-143 (2018). They constitute a further potential field of application for the category of pouvoir constituant mixte and, in states such as Canada, introduce a third level for struggles over constituent authority besides the state and provincial levels. Given however the paramount importance of historical injustice for the discussion of indigenous claims, which I cannot take up in this article, and given that indigenous sovereignty claims within settler states are most frequently based on declarations of self-determination, not independence referendums, I set them aside for the purposes of this article. I thank a reviewer for GLJ for suggesting I distinguish the cases.

${ }^{3}$ For state-of-the-art reviews from international law see Stefan Oeter, Sezession, territoriale Integrität und die Rolle des Sicherheitsrates, in Das Kosovo-Gutachten Des IGH vom 22. Juli 2002 ICJ Arts. \& Docs. 83-109 (Peter Hilpold ed., Martinus Nijhoff Publishers 2011); Self-Determination AND SECESSION IN InTERnAtional LAW (Christian Walter, Antje von Ungern-Sternberg \& Kavus Abushov eds.).

${ }^{4}$ The leading monographs are Andrew Arato, Post Sovereign Constitution Making. Learning and Legitimacy (2016) and Andrew Arato, The Adventures of the Constituent Power. Beyond Revolutions (2017). A discussion of procedural conditions on the exercise of constituent power was introduced in Andreas Kalyvas, Popular Sovereignty, Democracy, and the Constituent Power, 12 Constellations 223, 223-44 (2005).

${ }^{5}$ Peter Niesen, Reframing Civil Disobedience: Constituent Power as a Language of Transnational Protest, 15 J. INT'L PoL. THEORY 31, 31-48 (2019) [hereinafter Niesen, Reframing Civil Disobedience].
} 


\section{B. Pouvoir Constituant Mixte}

I use the term "federation" in a broad sense. Some states are federations, but federations of states (féderation, Bund) are not themselves states. ${ }^{6}$ For both types-federal states and federations of states - a monist and a dualist reconstruction of their constituent powers seems possible. In a dualist reconstruction, constituent power is assigned to the individual members ("the people") of the federation as well as to its constituent units, the member peoples or member states.

Traditional theory of constituent power is committed to monism-to assigning one and only one type of bearer of the pouvoir constituant to unitary states, federal states, and federations of states: While the constituent power in a state lies with its people, the constituent power in federations of states lies with the peoples of their constituent states. Monism usually contains an assumption that the mode of exercising constituent power in states is vertical, through hierarchical acts of legislation by the people or their delegates, while the mode of exercising constituent power in federations of states is horizontal, through procedures of constitutional contracting by their constituent peoples or their delegates. States are built on constitutional law, while federations of states are built on constitutional treaties. Where a federation of states historically develops into a state, its people absorb the respective constituent powers of the former units. ${ }^{7}$ This shows that monism is not so much committed to stable and immutable assignments of constituent power, but rather to the view that there exists one and only one bearer of it at any given moment in time.

Monism is the dominant view in constitutional law and political theory. Authors who diverge from this view in favor of a dualist view of constituent power clearly bear the burden of argument. Perhaps the most likely case for the emergence of a second constituent subject is where federations of states transform into ever closer unions. In some cases, such developments can be fully explained by monists. In the preamble of the 1871 Constitution of the German Reich, the constituent Länderfürsten self-identified as constituent powers, only to found a federal state and make themselves obsolete as pouvoirs constituants in the act. In contrast, the United States of America, despite being a federal state, is not a clear case for monism, given that constitutional change continues to depend on the member state populations. The best case for dualists is perhaps the European Union, which allows for the possibility that a new constituent subject could arise over and above-or below — the old constituent powers, leading to a distribution of dual constituent powers on two levels.

Even in the case of the European Union, the case is not settled. Markus Patberg distinguishes three positive 'narratives' of the allocation of constituent powers: demoi-cracy and regional cosmopolitanism, both monist views, and the pluralist pouvoir constituant mixte. ${ }^{8}$ Despite the persistent disagreements between monists and dualists regarding the basic legitimatory structure of the Union, one can still take some reassurance from the fact that they seem to agree on a methodological level and seem prepared to count the same developments and phenomena as evidence. All use a reconstructive methodology that allows them to identify both historical-originalist and developmental evidence, and to end up with what they claim is the best normative interpretation of the given institutional infrastructure. ${ }^{9}$ In the terminology of recent political theory, all accounts of constituent power in the EU are reconstructive and "practice-based", ${ }^{10}$ committed to reading off the seats of final political authority from the purpose and normative presuppositions of an

\footnotetext{
${ }^{6}$ Oliver Beaud, Théorie de la Fédération (2009).

${ }^{7}$ Carl Schmitt, Constitutional Theory (Jeffrey Seitzer trans. 2008) (1928) [hereinafter Schmitt, Constitutional THEORY].

${ }^{8}$ Markus Patberg, Constituent Power in the European Union ch. 3-5 (2020) [hereinafter Patberg, Constituent POWER].

${ }^{9}$ Peter Niesen, The 'Mixed' Constituent Legitimacy of the European Federation, 55 J. Common MкT. STUD. 183, 183-192 (2017) [hereinafter Niesen, 'Mixed' Constituent Legitimacy of the European Federation].

${ }^{10}$ Andrea Sangiovanni, How Practices Matter, 24 J. OF Pol. PHIL. 3, 3-23. (2016)
} 
institutional reality while they continue to differ in whether they assign constituent power to a collection of demoi, a regional supranational citizenry, or both.

The strongest evidence for a bifurcation of constituent powers is the introduction of the directly elected European Parliament, inducing a cross-border political status activus, and more generally the status and rights granted to them as citizens of the European Union. This supranational citizenship status is derived from and dependent on member state citizenship, as UK citizens learned when stripped of their European rights on January 1, 2021, but still sui generis. It goes beyond what federations of states traditionally did in subscribing to "intercitoyenneté," the reciprocal recognition of their respective citizenry by all parties to the federation, to which however no unified individual membership in the federation corresponds. ${ }^{11}$ The single unified citizenship status, manifested in political and other basic rights that flow from it, is crucial for the existence of a pouvoir constituant mixte.

It must be admitted, however, that the reconstructive method is both a strength and a weakness of recent writing on constituent power in that it neither allows for causal explanation or prognosis, nor does it commit to normative evaluations of polity transformation on the magnitude of Brexit. In countenancing counterfactual hypotheses, it abstracts away from the dynamics of actual constitutional change. Its strengths lie in identifying legitimate "ownership" of constituent authority, not in pin-pointing the sites where actual powers of constitutional change lie. It does allow for a denouncement of those actual powers in case they act as "constituent usurpers" 12 and push through any un-authorized constitutional change. At the same time, while the reconstructive method allows formulating the best normative interpretation of the existing institutions, thereby isolating abstractions which may then serve to recommend reforms, all such accounts are rationalizations ex post, that is, their ultimate justification lies in their suitability to interpret existing polity structures. It is hard to see how one could use the method to advertise full-scale constitutional revision, and not at all how to argue for legitimate polity change.

\section{Sub-State National Societies and Independence Referendums}

I now turn the problem of the fragmentation of uniform pouvoirs constituants within states. Traditional political and legal language identifies the people of a state as its pouvoir constituant as a matter of conceptual a priori. Transformation or disintegration of state constitutions is therefore a more dramatic matter than the exit from federations of states. When federations break up, the individual member states break away from one another, sometimes in accordance with the constitutional treaty. As in the case of the Lisbon Treaty, conditions for exit can be given in advance and invoked through referendums, parliamentary and executive decisions, and fixed in bilateral negotiations. In the internal disintegration of states, be they unitary or federal states, such a process is not envisaged, let alone constitutionally provided for. On the contrary, many federal countries have entrenched provisions parallel to Reichsexekution and Bundeszwang in successive German constitutions, provisions that make it impossible under given constitutional law for sub-state collectives to break away.

When assessing the legitimacy of exit referendums, the 2017 Catalan independence referendum is a productive example. Whatever else is at work in the relationship between Scotland on the one hand, and England and Wales on the other, the formation of a single polity goes back the Act of Union in 1707, so that, historically speaking, it may not be a hard case. Spanish democratic

\footnotetext{
${ }^{11}$ See Beaud, supra note 6. See also Niesen, 'Mixed' Constituent Legitimacy of the European Federation, supra note 9. While the introduction of federative citizenship seems to be the main driver of the development of a pouvoir constituant mixte, the more recent conflicts within the European Union seem to suggest that a ratchet effect has only been achieved through monetary union; see Perry Anderson, The Breakaway, 43 London Rev. Of Books 3-10 (2021) — a kernel of truth in an otherwise unconvincing account.

${ }^{12}$ Markus Patberg, Usurpation und Autorisierung. Konstituierende Gewalt im globalen Zeitalter (2018) [hereinafter PAtberg, Usurpation UND AUTORISIERUnG].
} 
statehood, in contrast, does not result from a founding treaty between its regions. Its constitutional law does not reflect horizontal agreements. In proceeding to delineate the discussion in the aftermath of the 2017 Catalan referendum, I cannot claim to cover the findings of international or constitutional law systematically. Largely relying on articles and blogposts from the same year, I approach the question inductively, building on the findings of international lawyers as applied to the case, and building on the findings of constitutional lawyers as applied to the same case. The confrontation seems instructive, because in their legal opinions on the Catalan independence referendum, assessments from international and constitutional law scholars could hardly differ more. I then move on to discuss a third alternative, departing from the work of Stephen Tierney.

From an international law perspective, the sub-state national society of Catalonia forms a collective which, in claiming a right to self-determination, already fulfills the jointly necessary and sufficient requirements, which are the existence of a "people," a territory, and a government. ${ }^{13}$ Thus, according to international law, the Catalans are entitled to assign themselves the status of a people, and thereby to legitimately ascertain the desire for self-determination and even for secession: "A group has a right to claim it is a people, and to design modalities how to ask people if they want self-determination, even secession." 14 Therefore, a group that can claim to be a people has the right to hold a referendum. However, this does not prejudice the validity or effectiveness of the referendum's result within international law. Discussions unfailingly add that consultative and even binding referendums do not constitute sufficient conditions for a secession, but quite generously pronounce on the legitimacy of the staging of an independence referendum itself.

In contrast, from the internal constitutional perspective of states, and thus of the Spanish constitution, the staging of an independence referendum is an attempted putsch. The Catalan parliamentary groups that passed the law on an independence referendum on September 6th and 7th, 2017, indisputably carried out a "constitutional coup d'état." ${ }^{15}$ Subsequent judicial persecution of the main actors involved has only underlined this view, as have the reactions of the European states and the European Union. But the reference to illegality does not exhaust the question of political legitimacy, given that the question whether the Spanish people's "constituent power is the only legitimate actor" is the very issue "to be queried in a referendum." 16 Nico Krisch admits that the Catalan independence referendum on October 1, 2017 was illegal according to the standards of the Spanish constitution, but argues that the Spanish constitution should not be considered the sole authority in the event of a conflict with Catalonia. This is due to the fact that the pouvoir constituant, the authoritative substrate on which the Spanish constitution is based, can no longer be referred to as unchallenged:

Like other constitutions, the Spanish one claims to be based on the pouvoir constituant of the people, in this case the Spanish people in which, according to Article 1 of the constitution, 'national sovereignty resides'. Yet this is a mere stipulation - the pouvoir constituant is always a social construction, a retrospective ascription to a body that does not exist as such. In some ways ... constituent power is always a fiction, though one with more or less resonance in societal beliefs. ${ }^{17}$

\footnotetext{
${ }^{13}$ Anne Peters, Populist International Law? The Suspended Independence and the Normative Value of the Referendum on Catalonia, EJIL:TALK!: BLOG OF THE EUR. J. INT'L L., Oct. 12, 2017, https://www.ejiltalk.org/populist-international-law-thesuspended-independence-and-the-normative-value-of-the-referendum-on-catalonia/.

${ }^{14}$ Martin Scheinin, Catalans May Not Have the Right to Unilateral Secession - But They Do Possess the Right to Present Such a Claim, BLOG OF THE IACL-AIDC, Sept. 10, 2017, https://blog-iacl-aidc.org/test-3/2018/5/25/catalans-may-not-have-theright-to-unilateral-secession-but-they-do-possess-the-right-to-present-such-a-claim.

${ }^{15}$ José Luis Martì, Seven Steps to Hell: the Catalan Conflict in Full Escalation Mode, VerfassungsblOG, Oct. 25, 2017, https://verfassungsblog.de/seven-steps-to-hell-the-catalan-conflict-in-full-escalation-mode/.

${ }^{16}$ Jaume López \& Marc Sanjaume-Calvet, The Political Use of de facto Referendums of Independence: The Case of Catalonia, 56 J. Representative Democracy 501, 501-519 (2020).

${ }^{17}$ Nico Krisch, The Spanish Constitutional Crisis: Law, Legitimacy and Popular Sovereignty in Question, VERFASSUNGSBLOG, Oct. 7, 2017, http://verfassungsblog.de/the-spanish-constitutional-crisis-law-legitimacy-and-popular-sovereignty-inquestion/ [hereinafter Kirsch, The Spanish Constitutional Crisis].
} 
Krisch's alternative perspective illustrates a third option, besides the views from international and constitutional law, to conceptualize independence referendums in sub-state national societies. According to this third view, the widespread dissatisfaction with uniform state constitutions did not arise out of general theories of federalism or trends toward decentralization, but from the resurgence of sub-state nationalism, as Stephen Tierney explained in a catalytic article. ${ }^{18}$ In some "multi-national" democracies, sub-state national societies have adopted the language of pouvoir constituant and described their devolutionist or separatist ambitions with recourse to it. Tierney observed that struggles over sub-state nationals' independence were struggles over constituent power: "[S]ub-state territories have been revitalized as political spaces within which radical, modern and democratic conceptions of constituent power are also mobilizing." ${ }^{19}$ Note the grammatical subject of the quoted statement: it is conceptions of constituent power that are mobilizing here, not necessarily constituent power itself that is stirring things up. This formulation displays not only Tierney's caution in stating the diagnosis, but at the same time illustrates the constructivist character of the commotions themselves that Krisch had insisted on. Tierney defends sub-state nationalisms in Quebec, Scotland, and elsewhere against the charge that they are necessarily pre-modern or anti-democratic, but shies away from asserting that the main actors in independence movement are straightforwardly deserving of constitutional recognition as bona fide instantiations of constituent power. ${ }^{20}$ With regard to Catalonia, Tierney describes the referendum as a "dramatic moment of direct democracy which usurps established constitutional understandings with the raw manifestation of what purports to be constituent power." ${ }^{21}$ Again, note the arms' length distance to the perspective of the actors involved in the formulation "what purports to be constituent power."

At the same time, Tierney does not find the statist alternative attractive. He argues that the "sociological" assumption that individual states are based on a uniform demos is often implausible and rejects Carl Schmitt's constitutional monism, if only to replace it with "plurinationalist" monism, the view that a unitary state should be understood as "a union of pre-existing peoples subsequent to which sub-state national societies within the state continued to develop as discrete demoi." 22 Tierney emphasizes that such sub-state national societies are often themselves not mere ethnic groups, but rather demoi, or civic nations, that are in no way inferior to the peoples of unitary states in terms of their republican ethos. In his eyes, the potential fate of unitary pouvoirs constituants may be not to fragment into ethnic or otherwise pre-political groups, but rather to decentralize into plural, future-oriented, republican territorial peoples. From the point of view of sub-state national societies, their states are therefore compound polities, "founded upon the principle of a union of free and equal nations." ${ }^{23}$ It remains to substantiate demands for the constitutional recognition of the host state's multinational basis, a task largely delegated to historiography.

Some of the cases discussed by Tierney can in fact revert to federative treaties, so that the federal semantics has a historical point of connection. For other processes of state-formation or democratic re-foundation, such as in Spain, this story of origins would need to engage in virtual history. But it is unclear whether entirely fictitious retrospectives of alleged federative origins can have significance for constitutional form. In such cases, narratives would have to rely on genealogies invented by the actors. This is not the method at work in the rational reconstructions

\footnotetext{
${ }^{18}$ Tierney, We the Peoples, supra note 1, at 229-45.

${ }^{19} I$ d. at 230. For a systematic account, see StePhen Tierney, Constitutional Referendums. The TheOry And Practice of Republican Deliberation (2012).

${ }^{20} \mathrm{His}$ even-handedness from an observer's point of view is further underlined by his parallel analysis of the Crimea independence referendum.

${ }^{21}$ Stephen Tierney, I-CONnect Symposium: The Independence Vote in Catalonia-Sovereignty Referendums: Constitutionalism in Crisis?, BLOG OF THE INT'L J. OF CONST. L. (Oct. 5, 2017), http://www.iconnectblog.com/2017/10/iconnect-symposium-the-independence-vote-in-catalonia-sovereignty-referendums-constitutionalism-in-crisis.

${ }^{22}$ Tierney, We the Peoples, supra note 1, at 232.

${ }^{23} I d$. at 234 .
} 
discussed earlier, if only because such hypothetical reconstructions allocate constituent power relative to an existing institutional order with obvious federative features. In the rational reconstructions at work in the debate over constituent power in Europe, the ideal-typical character of those narratives is conceded from the beginning, and any proposals for institutional change are flagged in a reformist manner. In contrast, in cases like Catalonia sub-state actors would be fabricating history if they claimed "legitimacy from the commitment to a fundamental constitutional moment; in other words, a sense that from the birth of the state, sub-state national societies were constitutionally entitled to distinctive accommodation within the state." ${ }^{24}$ Where the invocation of such a constitutional moment is fictitious, it may still be attempted to draw political legitimacy from the bootstrapping procedure of a constructivist narrative, as in Nico Krisch's intervention:

A composite constituent power may then be construed as the origin of the entirety of the constitutional order if the claim to represent is successful for all the different groups involved (even if it does not aim at transcending multiplicity in favor of a unitary collective subject). ${ }^{25}$

Such historical constructivism defies temporal logic, although it may still be effective politically. In an act of backward causation, the independence referendum of 2017 would have had to bring about an original, historically salient constituent power, which could then have served as a precondition for Catalonia successfully aspiring to independence. The Catalan autonomy movement precisely strived for a unilateral declaration of independence as a "declaration of constituent power" so that the existing state constitution could then be reinterpreted as that of a "union state." 6

\section{Lost Independence Referendums and the Pouvoir Constituant Mixte}

Is there an alternative to reading independence referendums as struggles for compound sovereignty? In his 2008 article, Tierney suggested that the E.U. should look to examples of plurinational states as "case stud[ies] in multinational coexistence." 27 Today, it seems that in a reverse direction of inspiration, actors in plurinational unitary states are increasingly attracted to re-imagining themselves and to re-designing their institutions using the model of federations of states. Perhaps even the Europhilia of some breakaway nations and regions such as Scotland and Catalonia can be interpreted as signaling sympathy for a multi-level distribution of sovereignty. Some moderate defenders of the constitutional recognition of sub-state nationalisms have attempted to reinterpret non-federated polities as federations of states, given that their current predicament appears constitutionally dysfunctional. Belgium is a case in point, as a state built on constitutional law, not a treaty, that grants autonomy status to regions and cultural units in a way that invites a construction as if it were built upon a pouvoir constituant mixte. ${ }^{28}$ Another important context of application is the UK constitution, which, building on the debate about a pouvoir constituant mixte for the European Union, ${ }^{29}$ could replace the notion of a unified British constituent people not by reverting to the compound demoi-cratic powers of England,

\footnotetext{
${ }^{24} I d$. at 235.

${ }^{25}$ Nico Krisch, Pouvoir Constituant and Pouvoir Irritant in the Postnational Order, 14 INT'L J. ConsT. L. 657, 657-79 (2016).

${ }^{26}$ See Tierney, We the Peoples, supra note 1 at 240-42. Tierney warns against reading domestic plurinational conflicts as "disputes between legitimate constitutional actors and unconstitutional sub-state rebels; they are disputes as to the very meaning of the constitution between two parties . . . instances of deep Kompetenz-Kompetenz disputation." Id. at 244 (italics in original).

${ }^{27} I d$. at 244.

${ }^{28}$ Stefan Rummens \& Stefan Sottiaux, Democratic Legitimacy in the Bund or 'Federation of States': The Cases of Belgium and the EU, 20 Eur. L.J. 568, 568-587 (2014). See also Helder de Schutter, Federalism as Fairness, 19 J. PoL. PHIL. 167 (2011) (constructing constituent dualism from a Rawlsian point of view).

${ }^{29}$ The EU's Pouvoir Constituant Mixte-Exploring the Systematic Potential of an Innovative Category, 55 J. COMMON MKT. STUD. 165, 165-222 (Markus Patberg ed., 2017).
} 
Wales, Scotland and Northern Ireland, but to a combination of both. Viewing the UK through the lens of a pouvoir constituant mixte would be capable of saving "the constituent power of the British people through disaggregation and then through reconstruction, allowing it to become not the presupposition, but the aspiration and normative reference point of the constitution." ${ }^{30}$ This would require to move on from a monistic (either compound or unitary) understanding to a dualist view of constituent authority for a plurinational state, along the lines of the model of the E.U. Is this the way forward for understanding independence referendums?

In the literature quoted in Section C. above, advocates of Catalonia's independence referendum have used the language of constituent powers in attempting to secure a replacement of, not a supplement to, the Spanish constitution's unitary foundation. But introducing the language of compound powers, in the best case, would turn Spain into a demoi-cracy. ${ }^{31}$ Based on a path-dependent transformation from a formerly unitary demos, this seems insufficient, given democratic standards of political freedom, political equality and distributive justice. As witnessed in the Brexit case, where British E.U. citizens were stripped of their civil and political rights despite their share in polity-wide political autonomy, a unilateral breakaway would leave those affected in their rights for self-determination without a say. ${ }^{32}$ Furthermore, the strategy of compound constituent powers amounts to doing away with the vertical, hierarchical element of democratic law-making, such that any remaining central state institutions would no longer be under unified democratic control, but governed by the checks and balances of horizontal bargaining. Self-determination strategies within non-federated states are all the more convincing where they are not themselves fueled by constitutional monism, neither aiming at secession nor compound sovereignty, but committed to achieving mixed, or dual, sovereignty under the description of "independence."

What are the chances of struggles over constituent power resulting in constituent dualism, and are independence referendums a good way to transform unitary states into federated states, built on a dualist understanding of constituent powers? It is important to note that independence referendums with decisional powers and clear and undisputable legal consequences are exceedingly rare, such that ex post legal interpretation and political negotiation are almost always mandated, regardless of their results. This lends credence to the observation that a central class of contemporary sovereignty referendums belong to the category of "leverage" referendums. ${ }^{33}$ The power of referendums lost, as in Quebec or Scotland, or won and outlawed, as in Catalonia, should not be underestimated, in that they lead to an improved bargaining position for the sub-state national actors vis-a-vis the center of the political system. Whereas the old "truism" in political science that whoever sets the terms of a referendum will win it has long been falsified, one lasting advantage of the staging of an independence referendum seems to be that the loser can repeat it, thus continuing to shape the future of the polity. Unitary democratic will-formation will live in the shadow of the exit referendum, which may provide a continuing threat to the polity and its central powers. From the perspective of a sub-state nationalist movement, an independence referendum cannot definitively be lost, especially if one's aim is to bring about a bona fide regional constituent power for stronger horizontal leverage and future escalation potential. In other words, referendums won, narrowly lost, or outlawed will necessarily succeed in creating or strengthening claims to constituent power. Whatever one might think of the legitimacy of the means used in their emergence, the

\footnotetext{
${ }^{30}$ Jo Erik Khushal Murkens, A Written Constitution: A Case Not Made, OxFord J. Legal StUd., May 3, 2021, https:// academic.oup.com/ojls/advance-article/doi/10.1093/ojls/gqab016/6262073.

${ }^{31}$ For a classic statement of demoi-cratic constituent power, see Francis ChEnEval, The Government of THE PEOPLES: On the Idea ANd Principles of Multilateral Democracy (2011). For applications to the European Union, see Kalypso Nicolaïdis, European Demoicracy and Its Crisis, 51 J. Common MKT. STUD. 351, 351-69 (2013) and Francis Cheneval \& Frank Schimmelfennig, The Case for Democracy in the European Union, 51 J. Common Mkt. STud. 334, 334-50 (2013).

${ }^{32}$ Markus Patberg \& Peter Niesen, After Brexit, the UK Should Have a Democratic Right of Return, LSE BREXIT BLOG (Oct. 30 , 2018), https://blogs.lse.ac.uk/brexit/2018/10/30/after-brexit-the-uk-should-be-able-to-re-enter-the-eu-if-it-wishes-to-do-so/.

${ }^{33}$ Marc Sanjaume-Calvet, Plebiscitarianism Revisited: A Typology of Independence Referendums, 54 CAN. J. POL. SCI. 593, 593-614 (2021).
} 
capacities for building on sub-state constituent power will have been improved. Referendums lost, or won and outlawed, are thus no-lose strategies for sub-state national societies in that they improve their bargaining position in constitutional—and normal-politics. They can be iterated when opportunity beckons, with Scotland as an example. Insofar as some independence referendums clearly and indisputably aim at secession, like in Slovenia, or re-affiliation, as in Crimea, in an hostile climate of international confrontation, it is undeniable that they amount to massive threats to constitutional stability. But in those cases where the struggle for independence referendums is understood, by many of those in the independence movements, as the struggle for the relative weight of the demoi-cratic vis-a-vis the unitary constituent element of one and the same state constitution, the spectre of "neverendum" raised by the two successive Quebec independence referendums in 1980 and 1995, ${ }^{34}$ and examined again after the 1994 independence referendum in Scotland, ${ }^{35}$ may lose its terror. "Independent Scotland" is a more inspirational T-Shirt slogan than "Toward pouvoir constituant mixte," but given political circumspection in formulation and post-referendum negotiations, lost and even narrowly won independence referendums could still be instrumental in giving increased recognition to constituent complexity within overarching democratic orders.

\section{E. Activating Constituent Powers: Conditions of Legitimacy}

In federal contexts, there is a "particularly high threshold for constituent action to be democratically legitimate, because a plurality of groups and actors must be considered in unstructured processes of deep transformation." ${ }^{36}$ Are lost or stunted independence referendums capable of surmounting this threshold? Given their potential benefits to the movements that push them through, what can be said about the conditions of legitimacy of staging independence referendums in general? While the conditions of legitimacy for secession have been discussed in detail in legal theory, legal philosophy and political theory, ${ }^{37}$ the prior question about independence referendums serving as a means of creating or replacing a polity's constituent units has not, to my knowledge, been separately addressed. In section C., I argued that the criteria of legitimacy provided by international or constitutional law are contradictory and aporetic, in that they either list necessary and sufficient substantive conditions that would allow us to identify a pre-existing "people" - in international law-or reject all potential for legitimate change in the allocation of constituent power-in constitutional law. It is more promising to look at the processes in which sub-state collectives attempt to trigger new powers. Three types of processes targeting a shift in the allocation of pouvoir(s) constituant(s) come to mind, in the articulation, activation, and exercise of constituent power. While exercise of constituent power effects changes in constitutional law, articulation invokes constituent power in arguing and campaigning for such changes. Activation, finally, is at the heart of the present topic and refers to activities that create, fuse, fragment, or change, constituent powers without thereby necessarily changing constitutional law. The case of articulation seems the least problematic, because, following Sieyès, the people as holders of constituent power can never be peremptorily bound by the existing constitution. ${ }^{38}$ Thus, articulation of constituent power on the part of the people is a unilateral, defeasible claim that political

\footnotetext{
${ }^{34}$ Christian Lammert, Referendum-Neverendum. Nationalismus und öffentliche Meinung in Quebec, in STAAT-NATIONDemokratie: Festschrift für Hans-JÜrgen Puhle 60-76 (Marcus Gräser, Christian Lammert \& Söhnke Schreyer eds., 1992).

${ }^{35}$ Aileen McHarg, Tom Mullen, Alan Page \& Neil Walker, The Scottish Independence Referendum: Constitutional and Political Implications (2016).

${ }^{36}$ Eva Marlene Hausteiner, (Re)-Constituent Power and Federal Change, 20 CONTEMPORARY POL. ThEORY 940, 944 (2021).

${ }^{37}$ For an interdisciplinary treatment, see PAu Bossacoma Busquets, Morality and Legality of SeCESSION: A TheORY of Self-Determination (Federalism and Internal Conflict) (Palgrave Macmillan 2019). Bauböck's is the first comprehensive account of secession from multi-level political systems. See Rainer Bauböck, A Multilevel Theory of Democratic Secession, 18 ETHNOPOLITICS 227, 227-246 (2019).

${ }^{38}$ Emmanuel JosePh SieYès, What is the Third Estate, in SieYès: PolitiCal Writings (Michael Sonenscher ed., 2003) (1789).
} 
movements are always free to raise. Political freedom entails that organizations and movements are free to lobby and campaign for independence as a shift in constituent power-if not always for unilateral declarations of secession. ${ }^{39}$ There is no way for liberal democratic states to legitimately restrict public narratives on the future allocation of constituent power. All dissenting, revolutionary, or revisionist articulation of constituent power must be free. In contrast, at the other end of the scale, conditions for the exercise of constituent power seem extremely demanding. Reserving disagreement on whether Catalans in fact make up a constituent power, one can safely say that the Catalan independence referendum uno actu amounted to its activation and attempted exercise. Although traditional doctrine holds that conditions of its exercise can never be fully specified in advance, ${ }^{40}$ there exists consensus in political theory that at least two necessary conditions hold, the first being full inclusion of stakeholders. ${ }^{41}$ Second, if officeholders lay claim to exercising constituent power, prior authorization besides the official channels of normal politics is necessary. ${ }^{42}$ These two conditions suggest that regional government-organized unilateral sovereignty referendums, as was the case in Catalonia, will generally lack legitimacy as exercises in constituent power, because they exclude stakeholders-Spanish citizens outside Catalonia — and are staged by constituted powers acting ultra vires. ${ }^{43}$ Some defenders of the Catalan independence referendum have argued that it was merely an instantiation of "civic protest and mobilization, which is all what people did in the end in polling stations in Catalonia." ${ }^{4}$ Others aimed to justify the referendum by claiming constitutional "freedom of peaceful assembly and of speech." ${ }^{45}$ But claims to "mere" articulation of constituent power in cases such as the Catalan referendum are spurious, as if a vote organized by regional government amounted to nothing more than the symbolic performance of acts of civil disobedience. Understanding the referendum as an attempt to break away from Spain, the Catalan regional government at the same time articulated and attempted to activate and exercise constituent power.

The preceding discussion of independence referendums not as instruments of exit-and therefore as exercises-but as means of activating new constituent powers, however, suggests that they do not answer to the same demanding criteria. If things go well-in other words, if the referendum is lost, outlawed, or narrowly won but not followed through-independence referendums can activate constituent powers for the foreseeable future, neither merely articulating constitutent power nor attempting to effect unmediated constitutional change. In terms of political legitimacy, such cases sit between articulation and exercise at the ends of a scale. Not all instances of activation may answer to the same criteria, however, and two categories seem particularly salient: The awakening of a dozing or dormant, but historically indisputable pouvoir constituant, as with Scotland, and the creation of a previously non-existent constituent power, as in Catalonia. In the former, though not in the latter case, at least historical legitimacy will be conferred on the re-activation of a constituent agent that can draw on a history of constitutional rhetoric. In both types of cases, strategies of activation can be pursued in the attempt to break away, or in the attempt to forge a unitary state into a more complex federation.

\footnotetext{
${ }^{39} \mathrm{~A}$ recent example from the European Union is the European Balcony Project, staging a theatrical proclamation of the European Republic and handing out fake European passports from theatre and municipal government balconies throughout Europe. The Balcony Project initiative of Nov. 2018, like other European Democracy Lab initiatives, was created by Ulrike Guérot and Robert Menasse. See European Democracy Lab, https://europeandemocracylab.org.

${ }^{40}$ Sieyès, supra note 38.

${ }^{41}$ Kalyvas, supra note 4 , at 223-44.

${ }^{42}$ Patberg, Usurpation und Autorisierung, supra note 12.

${ }^{43}$ Exceptions apply for omnilaterally pre-committed exit procedures.

${ }^{44}$ Martì, supra note 15.

${ }^{45}$ Albena Azmanova \& Barbara Spinelli, Open Letter to Commission President Juncker and European Council PREsident TUSK, Upholding the Rule of Law in the European Union, DiEM 25, June 11, 2017, https://diem25.org/ upholding-the-rule-of-law-in-the-european-union/.
} 
Even in the case where conditions for legitimacy can be more easily satisfied, a struggle for a two-level federation, with dualist, or "mixed", allocation of constituent power, would however need to be fought on both levels. Where the struggle for independence is understood as a struggle for the pouvoir constituant, as opposed to a struggle for secession, it is hard to see how it could be carried out unilaterally from within a uniform sub-state national collective given that pouvoir constituant mixte could be introduced in the rest of the polity as a result of a successful (in the sense of: lost or stunted) independence referendum. The other groups in the polity would have to be involved, as well as its overarching people, on the several levels. Even if a sub-state national community constitutes itself as a horizontal negotiating partner in a complex constitutional arrangement, and not as a sovereign people, the creation of this status cannot legitimately be achieved unilaterally.

\section{F. Conclusion}

Staging an independence referendum means securing a negotiation position that oscillates between a declaration of independence and a commitment to constitutional reform towards increased sub-state autonomy. Independence referendums gain their relevance not so much from the invention of a fantasized federative history, but from the formation of a new constitutional reality through the performative creation, revitalization, or consolidation of sub-state constituent powers. Whoever manages to organize an independence referendum thereby has a good chance of creating significant changes in the ontology of constituent powers, even in cases in which the referendum is lost at the ballots. The fact that failed independence referendums can be iterated is strong evidence for the diagnosis presented here, that they minimally serve to produce a "people" as bearer of constituent authority. This may also mean that "remainers", as opposed to "leavers" can never score a definitive victory. If Cameron had won the Brexit referendum, "by trying to appease the unappeasable, he was on a hiding to nothing: if the Europhobes had lost, they would simply have come back another time." 46 In contrast, independence referendums that are understood as struggles for leverage, and over the conditions of pouvoir constituant mixte rather than sovereignty, could be processed into permanent yet tolerable shadows accompanying plurinational democracies.

In independence referendums, movements and regional governments aim to articulate, activate, and exercise constituent power uno actu. These three courses of action markedly differ not only in their conditions of success, but also in their conditions of legitimacy. Articulation is a free for all activity, but government-implemented referendums are never just that. The least desirable course of events is that in which constituent power is simultaneously activated ex nihilo and exercised successfully-this case perhaps best exemplifies the manipulability of constituent power Carl Schmitt was dreaming of. ${ }^{47}$ It is hard to see how governmentally organized unilateral independence referendums can in general rule out this worstcase scenario, except perhaps in cases with a strong federative history. But there is a strong case to be made for staging independence referendums, especially losing referendums, as steps on the way to transforming unitary democratic state constitutions toward constitutions more sensitive to plurinational demands. Their path-dependency signals, however, that the shift from unitary democratic constitutions to a rivalling monist variant, this time of compound

\footnotetext{
${ }^{46}$ Geoffrey Wheatcroft, Yo, Blair!: Tony Blair's Disastrous Premiership (2007), quoted in Anderson, supra note 11.

${ }^{47}$ Carl Schmitt, Dictatorship: From the Origin of the Modern Concept of Sovereignty to Proletarian Class STRUGGLE 112-31 (Michael Hoelzl \& Graham Ward trans., 2013) (1921).
} 
constituent powers pitting regional collectives against each other, will be unsatisfactory. Lost independence referendums would amount to more progressive failures were they to aim not at demoi-cratic reconstitution, but at creating two-level constitutions, inspired by federations of states, and based on a commitment to a pouvoir constituant mixte. ${ }^{48}$

\footnotetext{
${ }^{48}$ I thank the participants of the Hamburg symposium on "Sovereignty Referendums and Constituent Power" in February 2021, especially Stephen Tierney, Markus Patberg, Eoin Daly, Leah Trueblood, and Anna Meine as well as an anonymous reviewer for their comments. The preparation of this article was funded by the DFG Grant NI 1181/6, "Reclaiming Constituent Power."
}

Cite this article: Niesen P (2022). Two Cheers for Lost Sovereignty Referendums: Campaigns for Independence and the Pouvoir Constituant Mixte. German Law Journal 23, 44-55. https://doi.org/10.1017/glj.2022.7 